$\begin{array}{rr}\text { JURNAL } & \text { Volume } 14, \text { Nomor 3, Mei 2018 } \\ \text { FIT(1)PATOLOGI } & \text { Halaman 89-96 } \\ \text { I N DON O S I } & \text { DOI: } 10.14692 / \text { jfi.14.3.89 } \\ \text { ISSN: } 0215-7950 & \end{array}$

\title{
Penggunaan Pelacak DNA untuk Deteksi Papaya ringspot virus dengan Metode Hibridisasi Asam Nukleat
}

\author{
Use of DNA Probe for Detection of Papaya ringspot virus Using \\ Nucleic Acid Hybridization Method
}

\author{
Irsan Nuhantoro, Kikin Hamzah Mutaqin, Sri Hendrastuti Hidayat* \\ Institut Pertanian Bogor, Bogor 16680
}

\begin{abstract}
ABSTRAK
Penyakit bercak bercincin yang disebabkan oleh Papaya ringspot virus (PRSV) merupakan salah satu penyakit yang paling merusak pada tanaman pepaya. Penyakit ini dilaporkan pertama kali di Indonesia pada tahun 2012 di Nangroe Aceh Darussalam, kemudian menyebar dengan cepat ke daerah pertanaman pepaya di Sumatera, Jawa, dan Bali. Selain menggunakan metode serologi atau polymerase chain reaction (PCR), pengembangan metode deteksi PRSV diperlukan untuk memfasilitasi upaya pencegahan penyebaran PRSV. Tujuan penelitian ini ialah mengonstruksi pelacak DNA untuk pengembangan metode deteksi berdasarkan metode hibridisasi asam nukleat. Karakterisasi molekul isolat PRSV dari Boyolali (Jawa Tengah), Medan (Sumatera Utara), Sleman (Yogyakarta) dan Tabanan (Bali) berdasarkan pada urutan gen HCPro menunjukkan bahwa keempat isolat memiliki tingkat kekerabatan yang tinggi dengan tingkat homologi, yaitu 97.9-99.1\%. Dua fragmen DNA spesifik gen HCPro dipilih sebagai pelacak DNA dengan pelabelan menggunakan bahan DIG-dioxigenin. Teknik hibridisasi asam nukleat dilakukan menggunakan kondisi optimum, yaitu stringency washes dengan $1 \times \mathrm{SSC}$ dan $0.1 \%$ SDS pada suhu $60^{\circ} \mathrm{C}$ selama 15 menit. Infeksi PRSV berhasil dideteksi dari beberapa sampel lapangan. Pelacak DNA PRSV yang dikonstruksi dari daerah HCPro memiliki kespesifikan tinggi dan kepekaan pada konsentrasi DNA yang rendah, yakni $0.062 \mu \mathrm{g} \mu \mathrm{L}^{-1}$.
\end{abstract}

Kata kunci: DIG-dioxigenin, HCPro, karakterisasi molekul, kloning DNA, polymerase chain reaction

\begin{abstract}
Papaya ringspot caused by Papaya ringspot virus (PRSV) is one of the most destructive diseases of papaya. The disease had not been found in Indonesia, until disease outbreak in Nangroe Aceh Darussalam was reported in 2012. Since then, the disease spread rapidly in most papaya growing areas in Sumatera, Java and Bali. Papaya ringspot virus (PRSV) is generally detected using serological or polymerase chain reaction methods. Improvement in detection method is necessary to facilitate a more reliable tool for controlling the spread of PRSV. The aim of the research was to construct DNA probe for development of detection method based on nucleic acid hybridization. Molecular characterization based on HCPro gene sequence indicated high homology (97.88 to 99.05\%) among PRSV isolates from Boyolali (Central Java), Medan (North Sumatera), Sleman (Yogyakarta) and Tabanan (Bali). Two DNA clones of HCPro gene were selected for probe construction and the probes were then labeled using PCR DIG-dioxigenin. Optimization of nucleic acid dot blot hybridization method to achieve strongest positive reaction was developed, i.e. using stringency washes at $1 \times \mathrm{SSC}, 0.1 \% \mathrm{SDS}$, incubation at
\end{abstract}

*Alamat penulis korespondensi: Departemen Proteksi Tanaman, Fakultas Pertanian, Institut Pertanian Bogor. Jalan Kamper, Kampus Darmaga IPB, Bogor 16680.

Tel : 0251-8629364, Faks : 0251-8629362, Surel : srihendrastutihidayat@gmail.com. 
$60^{\circ} \mathrm{C}$ for $15^{\prime}$. The DNA probe for PRSV has a high specificity and sensitifity; it could detect PRSV at the lowest concentration of nucleic acid $\left(0.062 \mu \mathrm{g} \mu \mathrm{L}^{-1}\right)$.

Key words : DIG-dioxigenin, DNA cloning, HCPro, molecular characterization, polymerase chain reaction.

\section{PENDAHULUAN}

Papaya ringspot virus (PRSV) merupakan patogen penting pada tanaman pepaya dan memiliki kemampuan menyebar sangat cepat sehingga dapat menimbulkan insidensi penyakit hingga 100\% (Sharma dan Tripathi 2014). PRSV termasuk famili Potyviridae, dengan kutudaun sebagai vektor yang menularkan secara nonpersisten (Kalleshwaraswamy et al. 2009). Dilaporkan terdapat dua tipe PRSV, yaitu PRSV tipe P dan PRSV tipe $\mathrm{W}$ yang memiliki tingkat kemiripan tinggi berdasarkan ciri morfologi dan serologi, tetapi berbeda dalam kisaran inang (Yeh et al. 1984).

Hidayat et al. (2012) melaporkan infeksi PRSV pertama kali di Indonesia terjadi di Provinsi Nanggroe Aceh Darusalam; sejak saat itu PRSV menyebar ke seluruh Indonesia. Berdasarkan Permentan no. 51 tahun 2015 dinyatakan bahwa PRSV termasuk sebagai organisme pengganggu tanaman karantina (OPTK) kategori A2 dengan daerah sebar di Sumatera, Jawa, dan Bali (Kementan 2015). Pencegahan penyebaran lebih lanjut dari PRSV perlu dilakukan dengan pemeriksaan kesehatan bibit tanaman pepaya mengingat tingginya lalu lintas perdagangan komoditas pertanian beberapa tahun terakhir ini. Oleh karena itu, metode deteksi yang cepat, tepat, dan akurat dibutuhkan dalam tindakan pemeriksaan karantina terhadap organisme pengganggu tanaman (OPT) terbawa oleh komoditas terutama untuk menekan risiko masuknya OPT ke wilayah baru.

Teknik deteksi menggunakan pelacak nukleotida telah banyak digunakan untuk mendeteksi patogen tanaman dengan tingkat kepekaan, kespesifikan, kecepatan, kemudahan, dan biaya yang tidak terlalu mahal (Wong dan Smart 2012). Komplementasi asam nukleat antara asam nukleat pelacak dan asam nukleat genom virus merupakan prinsip dasar dari hibridisasi. Metode deteksi nucleic acid dot-blot hybridization memiliki potensi untuk dikembangkan sebagai metode deteksi OPTK, khususnya PRSV. Pelacak DNA spesifik dapat dikonstruksi berdasarkan tingkat homologi genom. Salah satu gen yang memiliki kesamaan yang rendah di antara anggota Potyvirus ialah gen HCpro yang memiliki peranan penting dalam penularan Potyvirus secara mekanis dan melalui kutudaun. Gen HCPro memiliki tingkat variabilitas yang tinggi antarspesies pada famili Potyviridae, namun terdapat motif asam amino yang conserved (motif tersebut hampir ditemukan di semua anggota Potyviridae), yaitu Phe-Arg-Asn-Lys (FRNK) (Sahana et al. 2014). Selain menyebabkan kehilangan kemampuan ditularkan melalui vektor kutudaun, mutasi pada daerah FRNK pada isolat Zucchini yellow mosaic virus (ZYMV)-AG juga mengakibatkan tidak munculnya gejala yang tampak pada tanaman mentimun, melon, dan semangka (Jamous et al. 2011). Derajat kesamaan pada daerah FRNK tersebut dapat digunakan sebagai daerah target pelacak DNA. Keberadaan daerah FRNK pada gen HCPro PRSV penting karena dengan mendeteksi daerah tersebut dapat diperoleh informasi keberadaan infeksi PRSV sekaligus kemampuan penularan dan virulensinya.

Penelitian ini bertujuan mendapatkan klon DNA rekombinan gen HCPro PRSV yang akan digunakan sebagai pelacak DNA dalam metode deteksi nucleic acid dot blot hybridization.

\section{BAHAN DAN METODE}

\section{Karakterisasi gen $\mathbf{H C p r o}$}

Isolat PRSV dalam penelitian ini berasal dari tanaman pepaya yang diperoleh dari Tabanan (Bali), Boyolali (Jawa Tengah), 
Medan (Sumatera Utara), dan Sleman (DI Yogyakarta). Isolasi RNA total menggunakan kit komersial (QIAGEN RNAeasy). Metode RT-PCR digunakan untuk mengamplifikasi fragmen DNA. Sintesis cDNA menggunakan RevertAid M-MuLV reverse trancriptase (Thermo). Amplifikasi gen HCPro PRSV dilakukan menggunakan pasangan primer PRSV953-F 5'-GCGATGCTCATAAACATACCTGA-3' dan PRSV953-R 5'-TGTACACAGTAC TTCGGTGAGAAGTCGTA-3' (Tuo et al. 2014). Perunutan DNA dilakukan dengan mengirimkan DNA produk PCR ke FirstBASE Laboratories Malaysia. Penyuntingan sikuen DNA dilakukan menggunakan perangkat lunak Bioedit dan selanjutnya dianalisis dengan metode basic local alignment search tool (BLAST) pada perangkat lunak Geneious R10 versi 10.0.7. Penyejajaran sikuen DNA dan konstruksi pohon filogeni berturut-turut dilakukan dengan program MUSCLE dan metode Beyesian.

\section{Pembuatan Pelacak DNA}

Dua pasang primer spesifik gen HCPro, yaitu pasangan primer PRSV-84F/ PRSV185R dan PRSV-166F/ PRSV-305R dirancang untuk mengamplifikasi empat isolat PRSV (isolat Boyolali, Medan, Sleman dan Tabanan) (Tabel 1). DNA hasil amplifikasi dengan kedua pasang primer tersebut selanjutnya digunakan untuk kloning DNA menggunakan metode TA-cloning (Zhou dan Gomez-Sanchez 2000) dengan plasmid pTZ257R (Thermo scientific). Transformasi plasmid dilakukan dengan metode kimia (Thermo InsTAclone kit). Konfirmasi klon DNA rekombinan dilakukan beberapa tahap, yaitu seleksi klon
DNA rekombinan dengan metode seleksi putih biru, PCR koloni dengan primer M13, isolasi plasmid dan amplifikasi DNA target dengan primer spesifik, dan perunutan DNA. Klon DNA rekombinan yang telah terkonfirmasi dipilih, selanjutnya plasmid dipurifikasi mengikuti metode Tolmasky et al. (2007) dengan modifikasi pada beberapa tahapan, yaitu pembiakan bakteri pada media LB cair pada suhu $37^{\circ} \mathrm{C}$ selama 6-12 jam, pemanenan bakteri dengan sentrifugasi pada kecepatan $3000 \mathrm{rpm}$ selama 15 menit, dan presipitasi plasmid dengan sentrifugasi pada kecepatan $12000 \mathrm{rpm}$ selama 15 menit. Selanjutnya plasmid digunakan sebagai templat dalam pembuatan pelacak DNA.

\section{Hibridisasi DNA}

Sampel yang digunakan ialah isolat PRSV asal Boyolali, Medan, Sleman, dan Titigalar (Bali), dan isolat ZYMV. Masingmasing sampel uji disiapkan hingga diperoleh DNA hasil amplifikasi, selanjutnya dilakukan pengenceran bertingkat terhadap sampel DNA tersebut $\left(10^{0}, 10^{-1}, 10^{-2}, 10^{-3}\right.$, dan $10^{-4}$ ). Sampel positif dipilih dari sampel yang dapat diamplifikasi dengan primer MJ-1/MJ-2 dan PRSV953-F/PRSV953-R. Sampel negatif dipilih dari sampel yang dapat diamplifikasi dengan primer MJ-1/ MJ-2, namun tidak dapat diamplifikasi dengan primer PRSV953-F/PRSV953-R. Sampel negatif lainnya yang digunakan ialah sampel ZYMV yang diamplifikasi pada daerah HCPro dengan primer $\mathrm{HCProF}$ 5'-GTGATTCGAGGTAGAGACGA-3' dan HCProR 5'-CCAACTCTGTAATG TTTCAT-3' (Huet et al. 1994).

Tabel 1 Primer spesifik yang digunakan untuk membuat pelacak DNA

\begin{tabular}{llccc}
\hline Primer & \multicolumn{1}{c}{ Urutan Basa $\left(5^{\prime}-3^{\prime}\right)$} & $\begin{array}{c}\text { Ukuran } \\
(\mathrm{pb})\end{array}$ & Target Gen & $\begin{array}{c}\text { Lokasi } \\
(\mathrm{nt})\end{array}$ \\
\hline P1: & & & & \\
PRSV-84F & GGGAGTGGCCGACAATGTTA & 102 & HCPro & $2854-2955$ \\
$\begin{array}{l}\text { PRSV-185R } \\
\text { P2: }\end{array}$ & GATCAACAAGGATTCGCGGC & & & \\
PRSV-166F & GCCGCGAATCCTTGTTGATC & 140 & HCPro & $2936-3075$ \\
PRSV-305R & CACTATCGAGCGGCTCTCTG & & & \\
\hline
\end{tabular}


Pelabelan pelacak DNA dilakukan menggunakan DIG-dioxigenin dengan metode PCR labeling (Roche). Membran nitroselulosa $0.2 \mu \mathrm{M}$ (bioBasic) digunakan sebagai medium imobilisasi DNA sampel. Membran direndam dengan larutan denaturasi (0.5 M NaOH, 1.5 M NaCl), selanjutnya dicuci dengan larutan penetral $(1.5 \mathrm{M} \mathrm{NaCl}$, $0.5 \mathrm{M}$ Tris $\mathrm{pH}$ 7.4), kemudian dicuci dengan $2 \times$ SSC. Pre-hibridisasi dilakukan dengan menginkubasi membran dalam larutan $D I G$ Easy $\mathrm{Hyb}$ (Roche) pada suhu $42{ }^{\circ} \mathrm{C}$ selama 30 menit. Hibridisasi dilakukan dengan menginkubasi membran dalam $50 \mu \mathrm{L}$ pelacak DNA yang dilarutkan dalam $3.5 \mathrm{~mL} D I G$ Easy Hyb (Roche) pada suhu $42{ }^{\circ} \mathrm{C}$ selama 14-18 jam. Membran dicuci dengan 5× SSC, selanjutnya dicuci dua kali dengan larutan bufer hibridisasi $(1 \times \mathrm{SSC}$ dan $0.1 \% \mathrm{SDS})$ pada suhu $60{ }^{\circ} \mathrm{C}$ dengan digoyang pada kecepatan $100 \mathrm{rpm}$ selama 15 menit. Visualisasi reaksi hibridisasi dilakukan dengan metode kolorimetri menggunakan larutan substrat warna ( 1 tablet NBT/BCIP dalam $10 \mathrm{mLddH}_{2} \mathrm{O}$ ).

\section{HASIL}

Sampel tanaman sakit dari Boyolali, Medan, Sleman, dan Tabanan menunjukkan gejala khas infeksi PRSV, seperti yang dilaporkan sebelumnya oleh Gonsalves et al. (2010), Sharma et al. (2014), dan Chakraborty et al. (2015). Gejala yang diamati meliputi klorosis dan mosaik pada daun, bercak berminyak pada tangkai daun, dan bercak bercincin pada kulit buah (Gambar 1).

\section{Karakterisasi Gen $\boldsymbol{H C p r o}$}

Teknik RT-PCR menggunakan primer spesifik PRSV953-F/PRSV953-R berhasil mengamplifikasi fragmen DNA $\pm 953 \mathrm{pb}$ untuk 4 sampel daun sakit. Analisis sikuen DNA hasil amplifikasi berhasil menyejajarkan nukleotida sebanyak 943 pb dengan jumlah basa yang identik sebanyak 919 basa atau 97.4\% (Gambar 2). Tingkat homologi antara keempat isolat ialah 97.9-99.1\% (Tabel 2), yang menunjukkan bahwa PRSV isolat Indonesia tersebut memiliki kekerabatan yang tinggi. Lebih lanjut, analisis sikuen DNA empat isolat PRSV menunjukkan tingkat identitiy pairwise sebesar $98.6 \%$. Tingkat homologi yang tinggi antara empat isolat asal Indonesia menunjukkan bahwa isolat asal Indonesia (Boyolali, Medan, Sleman, dan Tabanan) memiliki kekerabatan yang tinggi. Homologi yang tinggi pada gen HCPro tersebut dapat digunakan untuk merancang pelacak DNA dengan memilih urutan nukleotida yang spesifik pada gen HCPro.

\section{Pembuatan Pelacak DNA}

Amplifikasi DNA PRSV dengan pasangan primer PRSV-84F/ PRSV-185R dan PRSV166F/ PRSV-305R menghasilkan pita DNA berukuran berturut-turut $102 \mathrm{pb}$ dan $140 \mathrm{pb}$.

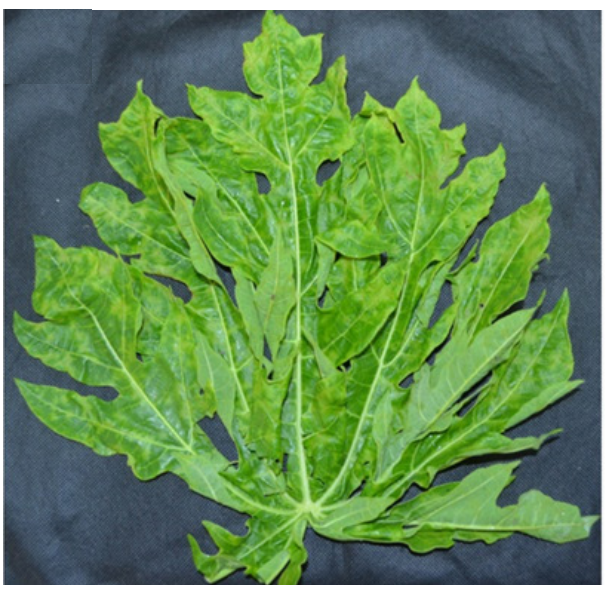

a

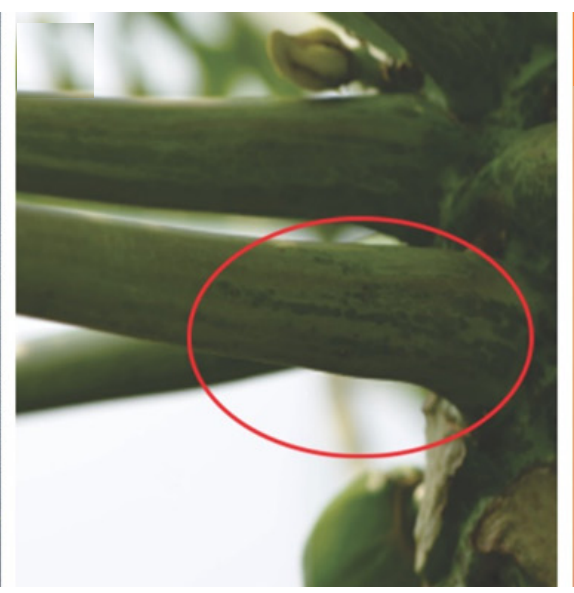

b

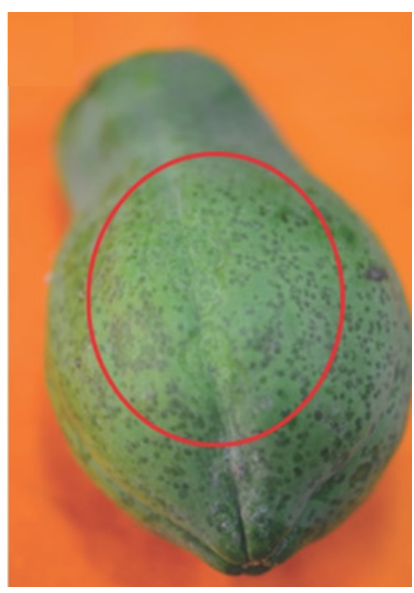

c

Gambar 1 Gejala infeksi PRSV pada tanaman pepaya. a, Mosaik pada daun; b, Bercak bergaris pada tangkai daun; dan c, Bercak bercincin pada buah. 
Identitas
Konsersus

1. Boyolali

2. Slemen

3. Medan

4. Tabanan

TTAGATGICG CGACATGCGC AAATCAATTG ATTATCTTTC ATCCCGATGC AGCCAATGCG GAATTGCCGC GaTCCTTGT TGATCATCGA CAGAAAaCAג TTAGATGICG CGACATGCGC AAATCAATTG ATTATCTTTC ATCCCGATGC AGCCAATGCG GAATTGCCGC GATCCTTGT TGATCATCGA CAGAAACA TTAGATGICG CGACATGCGC AAATCAATTG ATTATCTTTC ATCCCGATGC AGCCAATGCG GAATTGCCGC GATCCTTGT TGATCATCGA CAGAAAACAM

Identitas

Konsensus

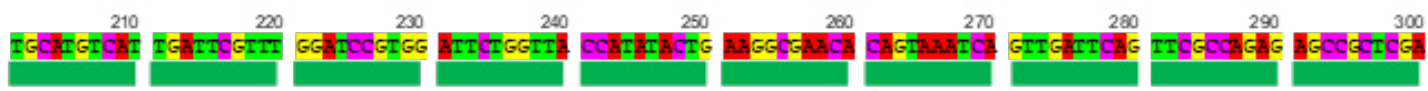

1. Boyolali

2. Slemen

3. Medan

4. Tabenan

TGCATGTCAT TGATTCGTTT GGATCCGTGG ATTCTGGTTA CCATATACTG AAGGCGAACA CAGTAAATCA GTTGATTCAG TTCGCCAGAG AGCCGCTCGA TGCATGTCAT TGATTCGTTT GGATCCGTGG ATTCTGGTTA CCATATACTG AAGGCGACA CAGTAAATCA GTTGATTCAG TTCGCCAGAG AGCCGCTCGA TGCATGTCAT TGATTCGTTT GGATCCGTGG ATTCTGGTTA CCATATACTG AAGGCGAACA CAGTAAATCA GTTGATTCAG TTCGCCAGAG AGCCGCTCGA

Identitas

Konsensus

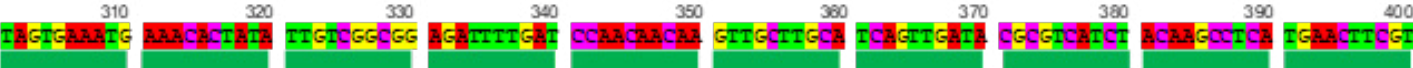

1. Boyolali

2. Sleman

3. Medan

TAGTGAATG AAACACTATA TTGTCGGCGG AGATTTTGAT CCAACAACAA GTTGCTTGCA TCAGTTGTA CGCGTCATCT ACAAGCCTCA TGAACTTCGT TAGTGAAATG AAACACTATA TTGTCGGCGG AGATTTGAT CCAACAACAA GTTGCTTGCA TCAGTGATA CGCGTCATCT ACAAGCCTCA TGAACTTCGT TAGTGAATG AAACACTATA TTGTCGGCGG AGATTTTGAT CCAACAACAA GTTGCTTGCA TCAGTTGATA CGCGTCATCT ACAAGCCTCA TGAACTTCGI

4. Tabenan TAGTGAaAT AAACACTATa TTGTCGGCGG AGATTTGAT CCAACAACAa GTTGCTTGCA TCAGTGATA CGCGTCATCT ACAAGCCTCA TGAACTTCGT

Identitas

Konsensus

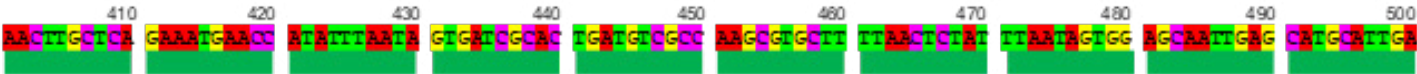

1. Boyolali

2. Slemen

3. Medan

AACTTGCTCA GAAATAACC ATATTTATA GTGATCGCAC TGATGICGCC AAGCGTGCTT TTAACTCTAT TTAATAGTGG AGCAATTGAG CATGCATTGa AACTIGCTCA GAAATAACC ATATTTAATA GTGATCGCAC TGATGTCGCC AAGCGTGCTT TTAACTCTAT TTAATAGTGG AGCAATTGAG CATGCATTGA AACTIGCTCA GAAATGAACC ATATTTAATA GTGATCGCAC TGATGTCGCC AAGCGTGCTT TTAACTCTAT TTAATAGTGG AGCAATTGAG CATGCATTGA

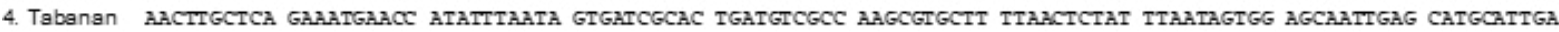

Identitas

Konsensus

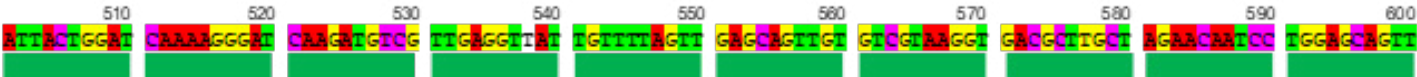

1. Boyolali

2 Slemen

3. Medan

4. Tabanan

ATTACTGGAT CAAAaGGGAT CAAGTGTCG TTGAGGTAT TGTTTTAGTT GAGCAGTTGT GTCGTAAGGT GACGCTTGCT AGAACAATCC TGGAGCAGTT ATTACTGGAT CAAAAGGGAT CAAGIGTCG TTGAGGTTAT TGTTTIAGTT GAGCAGTTGT GTCGTAAGGT GACGCTTGCT AGAACAATCC TGGAGCAGTT ATTACTGGAT CAAAAGGGAT CAAGTGTCG TTGAGGTTAT TGTTTTAGTT GAGCAGTTGT GTCGTAAGT GACGCTTGCT AGAACAATCC TGGAGCAGTI Identitas
Konsensus

1. Boyolali 2. Slemen

3. Medan

4. Tabanan

TAACGAGATT CGCCAAAACG CAAGGACAT ACATGAGCTA ATGGATCGGA ACAATAAGCC TTGGATTTCA TATGATCGAT CATTGGGCT ATTGAGTGTG TAACGAGATT CGCCAAAACG CAAGGACAT ACATGAGCTA ATGGATCGGA ACAATAAGCC TTGGITTCA TATGATCGAT CATTGAGCT ATTGAGTGTG TAACGAGATT CGCCAAAACG CAAGGACAT ACATGAGCTA ATGGATCGGA ACAATAAGCC TTGATTTCA TATGATCGAT CATTGAGCT ATTGAGTGTG TAACGAGATT CGCCAAAACG CAAGGACAT ACATGAGCTA ATGGATCGGA ACAATAAGCC TTGGTTTCA TATGATCGAT CATTGGAGT ATTGAGTGTG

Identitas

Konsensus

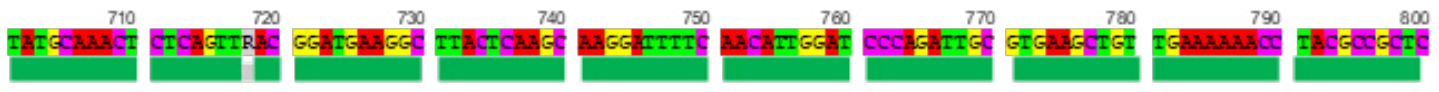

1. Boyolali

2. Slemen

3. Medan

4. Tabanan

TATGCAAACT CTCAGTIAC GGATGAGGC TTACTCAAGC AAGGATTTTC AACATTGGAT CCCAGATTGC GTGAAGCTGT TGAAAAACC TACGCCGCTC TATGCAAACT CTCAGTTGAC GGATGAAGGC TTACTCAAGC AAGGATTTC AACATTGGAT CCCAGTTGC GTGAAGCTGT TGAAAAAACC TACGCCGCTC TATGCAAACT CTCAGTTGAC GGATGAAGGC TTACTCAAGC AAGGATTTTC AACATTGGAT CCCAGATTGC GTGAAGCTGT TGAAAAAACC TACGCCGCTC TATQCAAACT CTCAGTTGAC GGATGAAGGC TTACTCAAGC AAGGATTTTC AACATTGGAT CCCAGATTGC GTGAaGCTGT TGAAAAAACC TACGCCGCTC

Identitas

Konsensus

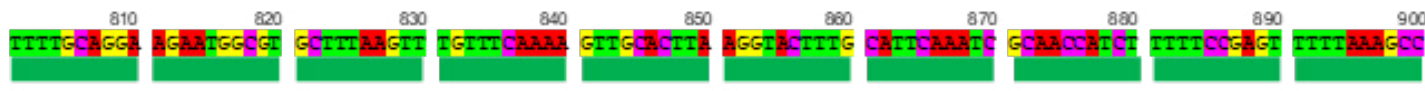

1. Boyolali

2. Slemen

3. Medan

4. Tabanan

TTTTGCAGGA AGAATGGCGI GCTTIAAGTT TGTTTCAAAA GTTGCACTTA AGGTACTTTG CATTCAAATC GCAACCATCT TTTTCCGAGT TTTTAAAGCC TTTTGCAGGA AGAATGGCGI GCTTTAAGTT TGTTTCAAAA GTTGCACTTA AGGTACTTTG CATTCAAATC GCAACCATCT TTTTCCGAGT TTTTAAAGCC TTTTGCAGGA AGAATGGCGI GCTTTAAGTT TGTTTCAAAA GTTGCACTTA AGGTACTTTG CATTCAAATC GCAACCATCT TTTTCCGAGT TTTTAAAGCC TTTTGCAGGA AGAATGGCGI GCTTTAAGTT TGTTTCAAAA GTTGCACTTA AGGTACTTTG CATTCAAATC GCAACCATCT TTTTCCGAGT TTTTAAAGCC

Identitas

Konsensus

1. Boyolali

2. Slemen

3 . Median

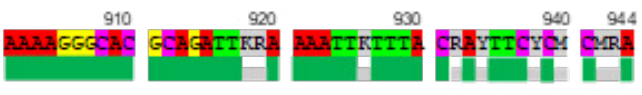

AAAAGGGCAC GCAGATTTA AAATTGTTTA CGACTTCTdA CCGA

AAAAGGGCAC GCAGTTIGA AAATTITTTA CGACTTCIOA CCAA

AAAAGGGCAC GCAGATGMA AAATTGTTTA CGACTTCTCA CCGA

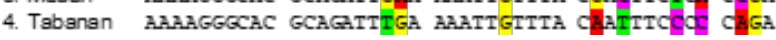

Gambar 2 Hasil pensejajaran urutan DNA sebagian daerah gen HCPro / P3 isolat Boyolali, Medan, Sleman, dan Tabanan. 
Tabel 2 Homologi sikuen nukleotida 4 isolat PRSV pada sebagian daerah gen HCPro dan P3.

\begin{tabular}{lccccc}
\hline \multirow{2}{*}{ Isolat virus } & No. aksesi & \multicolumn{4}{c}{ Homologi (\%) } \\
& GenBank & Sleman & Bali & Boyolali & Medan \\
\hline Sleman & LC222656 & 100 & & & \\
Tabanan & LC222653 & 99.1 & 100 & & \\
Boyolali & LC222654 & 98.6 & 98.9 & 100 & \\
Medan & LC222655 & 97.9 & 97.9 & 98.3 & 100 \\
\hline
\end{tabular}

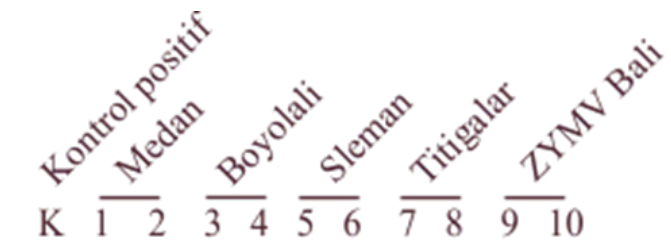

a

$\mathrm{b}$

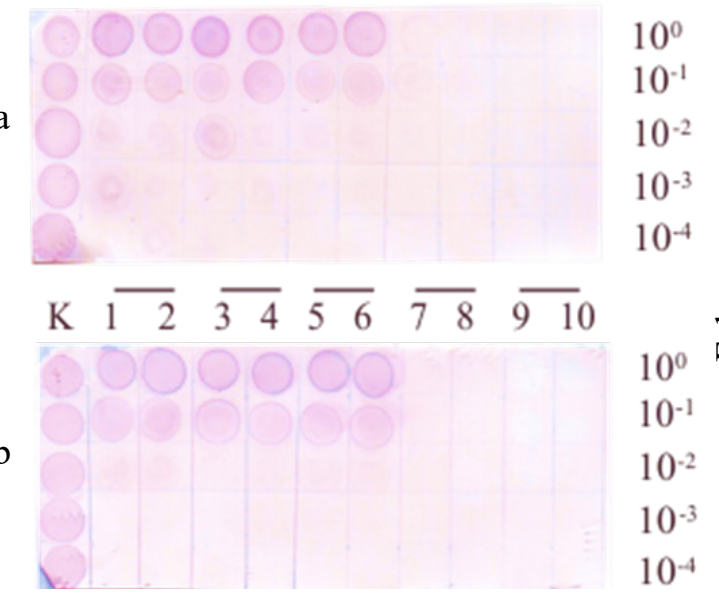

Gambar 3 Hibridisasi asam nukleat dengan pelacak DNA yang dihasilkan dari amplifikasi. a, Pelacak DNA pP1PRSV1; dan b, Pelacak DNA pP2PRSV1.

Kloning dua DNA fragmen tersebut menghasilkan beberapa klon DNA rekombinan. Konfirmasi dengan PCR koloni telah dilakukan, selanjutnya dipilih masing-masing satu klon DNA rekombinan pP1PRSV1 dan pP2PRSV1 untuk digunakan sebagai pelacak DNA dalam metode deteksi hibridisasi.

\section{Hibridisasi DNA}

Hasil hibridisasi menggunakan dua pelacak DNA yang berbeda dengan dilabel DIGdioxigenin berhasil mendeteksi keberadaan PRSV pada sampel positif, pada faktor pengenceran $10^{-1}$ dengan konsentrasi terendah sebesar $0.062 \mu \mathrm{g} \mu \mathrm{L}^{-1}$ (Gambar 3). Sampel negatif, yaitu sampel isolat Titigalar (Bali) dan ZYMV menghasilkan reaksi negatif terhadap pelacak DNA yang digunakan.

\section{PEMBAHASAN}

Hibridisasi adalah proses saat pelacak DNA menempel dan berpasangan dengan DNA atau RNA target yang merupakan komplemennya. Komplemantasi antara pelacak DNA dan DNA atau RNA target akan terjadi jika pelacak DNA memiliki urutan basa yang saling komplemen serta suhu dan waktu hibridisasi yang optimum. Urutan basa yang spesifik akan meningkatkan kespesifikan dari pelacak DNA tersebut. Yamagishi et al. (2006) melaporkan pelacak DNA yang spesifik dapat digunakan untuk membedakan empat galur dari Soybean dwarf virus (SbDV). Kespesifikan dari pelacak DNA yang dikonstruksi dari gen HCPro pada penelitian ini dirancang dari urutan basa nukleotida yang spesifik untuk mendeteksi keberadaan PRSV tipe P sekaligus mengetahui keberadaan gen HCPro yang memiliki peran dalam penularan melalui vektor.

Metode dot-blot hidridization telah lama digunakan sejak pertama kali dikembangkan pada tahun 1983 (Leary et al. 1983) serta banyak digunakan karena memiliki tingkat kepekaan dan kespesifikan yang baik. Pada penelitian ini sampel positif terdeteksi positif pada konsenstrasi $0.062 \mu \mathrm{g} \mu \mathrm{L}^{-1}$. Sampel negatif, yaitu isolat Titigalar dan ZYMV menghasilkan hasil deteksi negatif terhadap pelacak DNA yang digunakan. Hasil ini menunjukkan bahwa dua pelacak DNA yang digunakan memiliki kespesifikan dan kepekaan yang baik. Kespesifikan dan kepekaan dari pelacak DNA juga tidak dipengaruhi oleh panjang basa yang digunakan untuk pelacak DNA. Hal ini telah dilaporkan Juan et al. (2007) sebelumnya bahwa deteksi ZYMV, Water melon mosaic virus (WMV), Cucumber mosaic virus (CMV), dan PRSV 
tipe W yang dideteksi dengan pelacak DNA spesifik untuk masing-masing target dengan panjang basa yang berbeda menghasilkan tingkat kespesifikan dan kepekaan yang sama. Penggunaan pelacak DNA dengan urutan basa nukleotida yang lebih pendek akan menghemat penggunaan pelabel DIGdioxigenin. Penggunaan pelacak DNA yang digunakan secara berulang akan menghemat biaya deteksi patogen tanaman. Pelacak DNA pada penelitian ini digunakan secara berulang sebanyak 4 kali dan hasil deteksi pada tingkat kespesifikan dan kepekaan yang sama. Telah dilaporkan sebelumnya oleh Nageswara-Rao et al. (2013) pelacak DNA dengan label DIGdioxigenin dapat digunakan berulang sebanyak 12-15 kali tanpa kehilangan kespesifikan dan kepekaan .

Klon DNA yang mengandung sisipan gen HCPro PRSV dapat digunakan sebagai pelacak DNA dalam metode nucleic acid dot blot hybridization untuk mendeteksi infeksi PRSV pada tanaman pepaya. Penggunaan pelacak DNA dalam metode deteksi dengan tingkat kespesifikan dan kepekaan yang tinggi akan memberikan hasil identifikasi yang akurat terutama untuk mencegah masuk atau menyebarnya OPTK.

\section{UCAPAN TERIMA KASIH}

Terima kasih kepada Badan Karantina Pertanian yang telah membiayai penelitian ini.

\section{DAFTAR PUSTAKA}

Chakraborty P, Das S, Saha B, Sarkar P, Karmakar A, Saha A, Saha D, Saha A. 2015. Phylogeny and synonymous codon usage pattern of Papaya ringspot virus coat protein gene in the sub-Himalayan region of north-east India. Can J Microbiol. 61(8):555-564. DOI: https:// doi.org/10.1139/cjm-2015-0172.

Gonsalves D, Tripathi S, Carr JB, Suzuki JY. 2010. Papaya ringspot virus. The Plant Health Instructor. https://www.apsnet.org/ edcenter/intropp/lessons/viruses/Pages/
PapayaRingspotvirus.aspx. DOI: https:// doi.org/10.1094/phi-i-2010-1004-01.

HidayatSH, NurulitaS, Wiyono S. 2012. Infeksi Papaya ringspot virus pada tanaman pepaya di Provinsi Nanggroe Aceh Darussalam. J Fitopatol Indones. 8(6):184-187. DOI: https://doi.org/10.14692/jfi.8.6.184. Huet H, Gal-On A, Meir E, Lecoq H, Raccah B. 1994. Mutations in the helper component protease gene of Zucchini yellow mosaic virus affect its ability to mediate aphid transmissibility. J Gen Virol. 75(6):14071414. DOI: https://doi.org/10.1099/00221317-75-6-1407.

Jamous RM, Boonrod K, Fuellgrabe MW, AliShtayeh MS, Krczal G, Wassenegger M. 2011. The helper component proteinase of the Zucchini yellow mosaic virus inhibits the hua enhancer 1 methyltransferase activity in vitro. J Gen Virol. 92:2222-2226. DOI: https://doi.org/10.1099/vir.0.031534-0. Juan M, Qin-sheng G, Shi-ming L, Liu PB, Li-feng, Yan-ping T, Li L. 2007. Dot-blot hybridization for detection of five Cucurbit viruses by digoxigenin-labelled cDNA probes. Agric Sci China. 6(12):14501455. DOI: https://doi.org/10.1016/S16712927(08)60007-3.

Kalleshwaraswamy C, Krishna Kumar N, Dinesh M, Chandrashekar K, Manjunatha M. 2009. Evaluation of insecticides and oils on aphid vectors for the management of Papaya ringspot virus (PRSV). Karnataka J Agric Sci. 22(3):552-553.

[Kementan] Kementerian Pertanian. 2015. Peraturan Menteri Pertanian Republik Indonesia Nomor 51 Tahun 2015 tentang Perubahan Atas Peraturan Menteri Pertanian Nomor 93 Tahun 2011 tentang Jenis Organisme Pengganggu Tumbuhan Karantina. Jakarta (ID): Kementan.

Leary JJ, Brigati DJ, Ward DC. 1983. Rapid and sensitive colorimetric method for visualizing biotin-labeled DNA probes hybridized to DNA or RNA immobilized on nitrocellulose: Bio-blots. PNAS. 80(13):4045-4049. DOI: https://doi. org/10.1073/pnas.80.13.4045. 
Nageswara-Rao M, Miyata S, Ghosh D, Tuo D, Shen W, Yang Y, Yan P, Li X, Zhou Irey M, Garnsey SM, Gowda S. 2013. Development of rapid, sensitive and nonradioactive tissue-blot diagnostic method for the detection of citrus greening. Mol Cell Probes. 27(5-6):176-183. DOI: https:// doi.org/10.1016/j.mcp.2013.04.003.

Sahana N, Kaur H, Jain RK, Palukaitis P, Canto T, Praveen S. 2014. The asparagine residue in the FRNK box of potyviral helpercomponent protease is critical for its small RNA binding and subcellular localization. J Gen Virol. 95(5):1167-77. DOI: https:// doi.org/10.1099/vir.0.060269-0.

Sharma SK, Tripathi S. 2014. Papaya ringspot virus- $P$ : overcoming limitations of resistance breeding in Carica papaya $\mathrm{L}$. Di dalam: Gaur RK, Hohn T, Sharma $\mathrm{P}$, editor. Plant Virus-Host Interaction, $1^{\text {st }}$ Ed: Molecular Approaches and Viral Evolution. Oxford (GB): Academic Pr. hlm 177-194.

Tolmasky ME, Actis LA, Welch TJ, Crosa JH. 2007. Plasmid. Di dalam: Reddy C, Beveridge TJ, Breznak JA dan Marzluf G, editor. Methods For General And Molecular Microbiology. Washington (US): ASM Press.

P. 2014. Development and validation of a multiplex reverse transcription PCR assay for simultaneous detection of three papaya viruses. Viruses. 6:3893-3906. DOI: https://doi.org/10.3390/v6103893.

Wong MY, Smart CD. 2012. A new application using a chromogenic assay in a plant pathogen DNA macroarray detection system. Plant Dis. 96(9):1365-1371. DOI: https://doi.org/10.1094/PDIS-07-11-0593SR.

YamagishiN, Terauchi H, Honda K, Kanematsu S, Hidaka S. 2006. Discrimination of four soybean dwarf virus strains by dot-blot hybridization with specific probes. J Virol Methods. 133(2):219-222. DOI: https:// doi.org/10.1016/j.jviromet.2005.10.028.

Yeh S-D, Gonsalves D, Provvidenti R. 1984. Comparative studies on host range and serology of Papaya ringspot virus and Watermelon mosaic virus 1. Phytopathology. 74(9):1081-1085. DOI: https://doi.org/10.1094/Phyto-74-1081.

Zhou M-Y, Gomez-Sanchez CE. 2000. Universal TA cloning. Curr Issues Mol Bio. 2(1):1-7. 